\title{
THE FUTURE OF THE CUSTOMS UNION BETWEEN TURKEY AND THE EU IN THE CONTEXT OF THE TRADE POLICY AGENDA OF THE EU*
}

\author{
Mahmut TEKÇE**
}

\begin{abstract}
In the recent years, Turkey has been experiencing difficult times in the context of its perspectives on European integration. The future of the Customs Union between Turkey and the EU, which has been in effect for almost two decades, is blurrier than ever. The main reason of this is the sudden shift in the trade policy of the EU and the proliferation of EU's free trade agreements with third countries. During its implementation, the Customs Union with the EU had diverse effects in different sectors in Turkey, but after the EU announced its new trade policy "Global Europe" in 2006, Customs Union suddenly became a significant challenge for the Turkish economy. The shift in the trade policy of the EU has been alarming news for Turkey, where Turkey has faced a serious problem of trade deflection. As a consequence, Turkey has committed itself to taking the necessary measures and negotiating agreements on a mutually advantageous basis with the countries concerned.

The aim of this paper is to discuss the challenges of the Customs Union, the reasons and consequences of these challenges, possible ways to cope these hardships in the future and the effectiveness of Turkey's recent trade policies against possible losses in trade and customs revenues. After explaining the external trade policy of Turkey in the context of European economic integration, the paper discusses the negative consequences of the aggressive FTA strategy of the EU to Turkey's trade, and finally shows the unpreparedness of Turkish trade policy makers to this situation with examples of fallacious trade policy decisions. The methodology of the paper is mainly based on the policy analysis of case studies of the FTAs of both Turkey and the EU with common partners, by the comparison of tariff concessions and FTA coverage. In the light of the case studies, the future projections about the Customs Union agreement will be discussed.
\end{abstract}

Keywords: Integration, Turkey and the European Union, Trade Policy

JEL Classification: F02, F13, F15

* A previous version of this study was presented in 79th International Atlantic Economic Conference in Milan, Italy, 14 March 2015 and was supported by the Research Fund of the Marmara University. Project Number: SOS-D-110215-0046

** Associate Professor, Marmara University Department of Economics, Göztepe Campus, Istanbul, Turkey. Email: mtekce@marmara.edu.tr 


\section{AVRUPA BÍRLIGĞI'NİN DIŞ TÍCARET POLITIKASI GÜNDEMI BAĞLAMINDA TÜRKIYE - AB ARASINDAKI GÜMRÜK BİRLİĞİ'NİN GELECEĞ́̇}

\section{$\ddot{O}_{z e t}$}

Türkiye son yillarda Avrupa Birliğ̈i’ne entegrasyon sürecinde zorluklar yaşamaktadır. Türkiye ve $A B$ arasında yaklaşık yirmi yıldır yürürlükte olan Gümrük

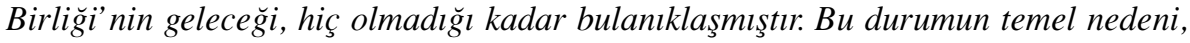
$A B$ ' nin diş ticaret politikasındaki keskin de ğişim ve AB' nin üçüncü ülkelerle yaptığ serbest ticaret anlaşmalarının sayısının artmakta olmasıdır. Gümrük Birliği, Türkiye ekonomisindeki sektörlere farklı şekillerde etkili olmus, ancak 2006 yılında AB' nin "Küresel Avrupa” dış ticaret politikasını açıklamasının ardından Türkiye ekonomisi için önemli bir zorluk haline gelmiştir. Türkiye, AB' nin bu politikast sonucunda ciddi bir ticaret sapması tehlikesi yaşamaktadır. Bu durumun bir sonucu olarak, Türkiye dış ticaret politikalarını AB'nin anlaşma yaptı̆̆ ortak zeminde buluşma ve karşılıkl avantaj elde edilecek şekilde anlaşma yapmak yönünde yeniden şekillendirmiştir.

Bu makalenin amacı Gümrük Birliği’ nin önündeki zorluklarl incelemek, bu zorlukların neden ve sonuçlarını analiz etmek ve bu durumdan en az zararlı çıkabilmenin olast yollarını tartışmaktır. Bu bă̆lamda Türkiye’nin güncel dış ticaret politikalarının diş ticaretteki ve gümrük gelirlerindeki azalma riskine karşı ne ölçüde etkili olduğu tartışlmaktadır. Türkiye’ nin dış ticaret politikası AB entegrasyonu bă̆lamında incelendikten sonra AB' nin aktif serbest ticaret anlaşması politikasının Türkiye' nin diş ticaretine olumsuz etkileri tartışılmakta ve Türkiye' nin bu duruma karşı hazırlıksız olduğu, hatalı dış ticaret politiaksı örnekleri bağlamında açıklanmaktadır. Makale yöntem olarak karşılaştırmalı politika analizine dayanmakta ve tarife oranlarındaki azaltmalar ve anlaşma kapsamları AB ve Türkiye' nin aynı partner ülkeyle yapılan serbest ticaret anlaşmalarında incelenmektedir. Bu karşılaştırmaların ışığında Gümrük Birliğı’ nin gelece ği tartışılmaktadır.

Anahtar Kelimeler: Entegrasyon, Türkiye ve Avrupa Birliği, Dlş Ticaret Politikasl

JEL Sinıflaması: F02, F13, F15

\section{Introduction}

In the recent years, Turkey has been experiencing hard times in the context of its perspectives on European integration, and the future of the Customs Union between Turkey and the EU, which has been in effect for almost two decades, is blurrier than ever. One of the main reasons of this challenge is the EU's sudden shift in the trade policy and its proliferation of free trade agreements with third countries.

The aim of this paper is to discuss the challenges of the Customs Union, the reasons and consequences of these challenges, possible ways to cope these hardships 
and the effectiveness of Turkey's recent trade policies against possible losses in trade and customs revenues. After explaining the external trade policy of Turkey in the context of European economic integration, the paper discusses the negative consequences of the aggressive FTA strategy of the EU to Turkey's trade, and finally shows the unpreparedness of Turkish trade policy makers to this situation with an example of a fallacious trade policy decision. The methodology of the paper is mainly based on the policy analysis case study of the FTAs of both Turkey and the EU with a common partner, Korea, and the comparison of tariff concessions given by Korea to Turkey and the EU clearly shows why this case study is chosen as a fallacious trade policy example.

\section{Trade Policy of Turkey and the Customs Union with the EU}

Turkey has adopted an export-oriented growth strategy since the early 1980s and liberalized its foreign trade gradually since then. In line with this strategy, Turkey has been aiming at integrating its economy with the European Union (then the European Community) since the 1960s. Turkey's efforts of adopting its markets and institutions for a prospective integration with Europe accelerated after mid-1980s, where eventually the Customs Union agreement has been in effect since January 1, 1996. This agreement was regarded as the last required step towards full membership of Turkey to the EU, and at that time, Turkey's accession into the EU was expected to take place in a near future.

The formation of the Customs Union with the EU in 1996 became a turning point in Turkey's external trade policy as Turkey brought its trade policies in line with the Common Commercial Policy of the EU. With the Customs Union, all customs duties and quantitative restrictions in the trade of industrial products between Turkey and the EU were removed and Turkey adopted the common external tariffs of the EU on imports from third countries. Agricultural goods were regarded as sensitive products for both parties and were left out of the context of the Customs Union. According to the Decision No. 1/95 of the Turkey-EC Association Council, ${ }^{1}$ free movement would be valid for goods either wholly produced in either parts of the agreement or put in free circulation after their importation from third countries in either Turkey or the EC. The proof of this customs status of "goods in free circulation" is established by an ATR.1 movement certificate. Customs Union also requires the approximation of customs law, intellectual property rights, competition and taxation regimes.

The effects of the Customs Union to the Turkish economy have been discussed widely since its implementation. The most visible effect of the Customs Union was the exposure of Turkish producers to the competition from the European importers and also the possibility of Turkish exporters to operate in one of the largest free trade areas in the world. Kaminski and $\mathrm{Ng}^{2}$ assessed effects of the Customs Union to the

1 Full text available at http://www.abgs.gov.tr/files/_files/Gumruk_Isbirligi/okk1.pdf

2 B. Kaminski and F. Ng, "Turkey's Evolving Trade Integration Into Pan-European Markets", Journal of International Trade and Diplomacy, 1 (2), 2007, pp. 35-103 
Turkish economy in terms of the technological content of Turkish exports and showed that although low-technology products outweigh, there has been a dramatic shift from medium and high-technology exports thanks to the orientation to the European markets. Adam and Moutos ${ }^{3}$ argued that, as the Customs Union between EU and Turkey allows Turkey only limited access to the EU's internal market, the larger part of the positive effects of goods market integration is expected to materialize only after the full membership of Turkey to the EU.

The Customs Union had diverse effects in different sectors, but after the EU announced its new trade policy in 2006, the Customs Union became a significant challenge for the Turkish economy. The EU has been keeping a multilateralist position in global trade policy after the formation of the WTO in 1995. Especially after the start of the Doha round of the WTO, the trade policy of the EU was "pursu[ing] all existing mandates for regional negotiations with vigor and fairness, but not to begin any

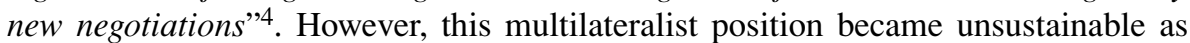
the negotiation talks in Geneva failed to reach an agreement and the Doha round was officially suspended in July 2006. Regarding the fact that the biggest competitor, the US, has been pursuing free trade agreements (FTAs) with several countries, especially with the developed and emerging markets in East Asia, the EU had to act as soon as possible to avoid trade diversion and a shift in the EU's trade strategy had already become inevitable.

\section{Consequences of the Shift of the EU's Trade Policy on Turkey's Trade with Third Countries}

The European Commission revealed a new trade policy strategy, Global Europe $^{5}$, in October 2006, under which the EU would pursue bilateral FTAs with major economies in order to secure the market access and competitiveness of European companies in important markets. The core of the new trade strategy of the EU has been summarized by the Commission as; "rejection of protectionism at home, accompanied by activism in creating open markets and fair conditions for trade abroad"6. The FTA strategy constitutes a very important part of this trade policy. The EU already has quite a large number of bilateral deals: the agreements with the EFTA countries, the Customs Union with Turkey, the goods agreements with the Euromed countries and the preferential arrangements offered to the sub-Saharan African, Caribbean and Pacific (ACP) countries. The EU had also signed FTAs with Chile, Mexico and South Africa. In the Global Europe strategy, the European Commission defined the key eco-

3 A. Adam and T. Moutos, “The Trade Effects of the EU Turkey Customs Union”, World Economy. 31 (5), 2008, pp. 685-700

4 P. Lamy, "Stepping Stones or Stumbling Blocks? The EU's Approach Towards the Problem of Multilateralism vs Regionalism in Trade Policy", World Economy, 25, p. 1412

5 Full text available at: http://trade.ec.europa.eu/doclib/docs/2006/october/tradoc_130376. pdf

6 European Commission, Global Europe: Competing in the World, Commission Staff Working Document, DG External Trade, Brussels, 2006, p. 6 
nomic criteria for new FTA partners as market potential and the level of protection (tariffs and NTBs) against EU export interests, and set the prior targets as ASEAN, Korea and Mercosur. India, Russia and the Gulf Cooperation Council were defined as the countries of direct interest, and significant importance has been attached to an empowered Transatlantic trade partnership ${ }^{7}$.

The EU quickly took action in the context of its new trade policy and started FTA negotiations with Korea and ASEAN in 2007 with Mercosur in 2010. The first results of this FTA-oriented trade strategy of the EU were achieved by the signature of the EU-Korea FTA in 2010, where the agreement has been in effect since July 2011. The negotiations with ASEAN has been paused in 2009 and re-launched in 2010, but only with Singapore and Malaysia. Moreover, the EU started FTA negotiations with Canada in 2009 and last, but absolutely not the least, the USA and the EU have been negotiating over a Transatlantic Free Trade Area since 2013. ${ }^{8}$

The shift in the trade policy of the EU has been alarming news for Turkey. According to the Article 16 of the Customs Union agreement, Turkey has to align itself progressively with the preferential customs regime of the EC within five years from the date of entry into force of the Customs Union, where this alignment will concern both the autonomous regimes and preferential agreements with third countries. To this end, Turkey committed itself to taking the necessary measures and negotiating agreements on a mutually advantageous basis with the countries concerned.

As the EU paced its efforts for FTAs with larger countries, Turkey has faced a serious problem of "trade deflection". According to Krueger", when the transport costs are assumed zero, any FTA would become a customs union, where importers would import goods through the country with the lowest tariff and then transship (or deflect) them to the country where they were in demand. In order to avoid such negative consequences of a Customs Union, rules of origin become a central feature of both Customs Union and Free Trade agreements. As Francois et al. ${ }^{10}$ stress, all preferential trade agreements require rules of origin to prevent trade deflection and the European Union insists on its own rules of origin being applied in all of its preferential trade agreements, and determining the origins becomes complex when processing or manufacturing uses imported intermediate material in production, since both parties will wish to exclude from preferences, third country goods which have undergone only superficial working or processing in the partner country.

7 Ibid, pp. 10-11

8 See the European Commission's portal on TTIP; http://ec.europa.eu/trade/policy/in-focus/ ttip/ and J. Kanter and J. Ewing, "A Running Start for a U.S.-Europe Trade Pact”, The New York Times, 13.02.2013: http://www.nytimes.com/2013/02/14/business/ global/obamapledges-trade-pact-talks-with-eu.html

9 A. O. Krueger, Problems with Overlapping Free Trade Areas, in Regionalism versus Multilateral Trade Arrangements, T. Ito and A. O. Krueger (eds.), University of Chicago Press, 1997

10 J. F. Francois, M. McQueen and G. Wignaraja. "European Union-developing country FTAs: overview and analysis." World Development, 33.10, 2005, p. 1554. 
As mentioned above, the ATR.1 movement certificate is sufficient for the free circulation of goods within the Customs Union area. Once the EU signs an FTA with a third country, the partner country accesses the EU market without any customs duties as long as it receives an ATR.1 certificate in one of the member countries, which means unrestricted access to Turkish markets. Turkey, on the other hand, finds itself in a position of opening its markets to countries that it did not even negotiate with, and under conditions determined by the interests of the EU and the partner country. Furthermore, it will face trade barriers on the markets of that country. This not only puts Turkey in an uneven position in its bilateral trade with the partner country, but also leads to a serious fall in its customs revenues.

Turkey expressed its complaints to the European Commission, and demanded the EU to give Turkey a role in the FTA negotiations or to bind the partner to pursue simultaneous FTA talks with Turkey; however these attempts have not succeeded. The European Commission states that it negotiates its free trade agreements on behalf of its 28 member states only, and the inclusion of Turkey is practically impossible.

Before the announcement of the new "Global Europe" trade policy strategy of the EU in 2006, Turkey also faced the problem of trade deflection, but the EU's FTA partners were either relatively small in economic size or had a small trade volume with Turkey. As stated in Article 16 of the Customs Union agreement, Turkey would take the necessary measures and negotiate agreements with the EU's FTA partners, but some of these counties, like Algeria, South Africa and Mexico, have been reluctant to start FTA negotiations with Turkey. As Turkey fails to come to an agreement with the country that signed an FTA with the EU, and the time lag between the FTAs of two parties expands, Turkey's loss from trade deflection rises. The table below shows the completed FTAs of the EU after 2000 and their comparison with Turkey.

Table 1: Comparison of the FTAs of Turkey and the EU

\begin{tabular}{|l|l|l|}
\hline \multirow{2}{*}{ Country } & \multicolumn{2}{|c|}{ Year the FTA Came into Force } \\
\cline { 2 - 3 } & EU & Turkey \\
\hline Mexico & 2000 & Negotiations did not start \\
\hline Morocco & 2000 & 2006 \\
\hline South Africa & 2000 & Negotiations did not start \\
\hline Jordan & 2002 & 2011 \\
\hline Lebanon & 2003 & Negotiations in progress \\
\hline Egypt & 2004 & 2007 \\
\hline Algeria & 2005 & Negotiations did not start \\
\hline Chile & 2005 & 2011 \\
\hline Korea & 2011 & 2013 \\
\hline
\end{tabular}

Source: Republic of Turkey Ministry of Economy FTA portal (2015)

As seen in the table, there is a time lag between the partner countries' FTAs with the EU and Turkey, which increases the costs of trade deflection for Turkey. Still, the relatively small economic size of these countries made this loss acceptable to some extent. However currently the EU is negotiating or has completed FTAs with larger 
economies and with a deeper coverage. Turkey faces serious challenges in this process; first of all, there is no binding clause for these counties to sign an agreement with Turkey, they may want to enjoy the tariff-free access to Turkey if they have concerns about opening their own markets to Turkey. Second, it is the first time for Turkey to negotiate an FTA with country groups (except for Turkey-EFTA FTA in 1992) instead of single countries, and also to negotiate deep FTAs instead of agreements with only tariff and quota removal. So far, Turkey has completed 17 FTAs and is negotiating 13 FTAs at the moment.

Negotiating these FTAs with the broad coverage as the EU conducts will be a challenge for Turkey's foreign trade policy in the forthcoming years. Each FTA has its own risks and opportunities which is and will be examined by policy makers and related institutions. But the current position of Turkey is as follows; as a result of the Customs Union with the EU, Turkey is unable to select its FTA partners in line with its economic interests, has to pursue the EU's FTA partners for an agreement, and faces trade deflection especially as the EU plans FTAs with large economies (like Canada and USA) unless Turkey signs FTAs with these countries immediately as the EU signs.

\section{Fallacies in Turkey's Trade Policies: The Case of Korea-Turkey FTA}

As mentioned above, after the EU's FTA with Mexico and South Africa, Turkey approached both countries for a parallel FTA in order to avoid a possible trade deflection from these countries, however both Mexico and South Africa have been reluctant to negotiate an FTA with Turkey. It has been different when Turkey approached Korea after Korea's FTA with the EU; the negotiations that started in March 2010 were successfully completed in August 2012 and the FTA has been in effect since May 2013.

The FTA between Korea and Turkey has been set up as an agreement that would go far beyond a simple FTA. The agreement covers areas more than tariff elimination and also focuses on areas like intellectual property rights, competition policy, consultations and dispute settlement, transparency and institutional framework for policy dialogues.

The position of Turkey and Korea before the FTA was that, thanks to its FTA with the EU, Korea had a possibility to export their products initially to the EU, and then enter Turkey tariff-free by taking advantage of the Customs Union, if the transportation and commission costs of these transactions are below the costs arising from paying customs duties in Turkey. Even if the product in question is subject to customs duties when entering the EU, which has not been completely removed but has been lowered by the FTA, again Korean exporters to Turkish markets would choose to enter Turkey via the EU if the sum of the transportation and commission costs and the duties paid to the EU is lower than the duties paid to Turkey. In this case, an important part of Turkey's customs revenues would shift to the EU countries. On the other hand, the Turkish side, at least for certain sectors, would not be motivated to conclude an FTA with Korea, as the benefits would be limited. Turkey's exports to Korea is less 
than one tenth of its imports from Korea, and the main reason for this low value of exports is not seen as the level of the tariff barriers (except for the agricultural products), but mainly as the fact that, there is no actual market for Turkey's main export items in Korea. In other words, the products that represent large shares in Turkey's exports, like motor vehicles, iron and steel, textile products and electrical machinery, are already extensively produced in and exported from Korea. Therefore, the FTA was expected to have very limited gains to the Korean side, and Turkey was expected to gain from the agreement if and only if the FTA creates new areas of export, those have been previously non-existent or very low because of high tariff rates. In this sense, the best scenario for Turkey would have been elimination or significant reductions of tariffs in products that Korea does not produce and imports, EU have been enjoying tariff cuts thanks to the FTA, and Turkey is a net exporter.

Table 2 below shows the product groups in two-digit HS classification where Korea is a net importer and Turkey is a net exporter. Table shows the average, minimum and maximum tariff rates applied to Turkey and the EU before the FTAs, and their post-FTA levels both applied to Turkey and the EU.

\section{Table 2: Comparison of Korea's Tariff Concessions for Turkey and the EU after the FTA}

\begin{tabular}{|c|c|c|c|c|c|c|}
\hline \multirow[t]{2}{*}{$\begin{array}{l}\text { HS } \\
\text { CODE }\end{array}$} & \multirow[t]{2}{*}{ Description } & \multicolumn{3}{|c|}{$\begin{array}{c}\text { Korean Tariffs } \\
\text { before the FTA } \\
(\%)\end{array}$} & \multicolumn{2}{|c|}{$\begin{array}{l}\text { Timing for the elimination of Korean } \\
\text { Tariffs after the FTA with; }\end{array}$} \\
\hline & & Min & Max & Avg & Turkey & $\mathbf{E U}$ \\
\hline 02 & $\begin{array}{l}\text { Meat and edible meat } \\
\text { offal }\end{array}$ & 3 & 40 & 23 & $\begin{array}{l}\text { No change, very } \\
\text { few } 10 \text { yrs }\end{array}$ & mostly immediate \\
\hline 03 & $\begin{array}{l}\text { Fish and crustaceans, } \\
\text { molluscs }\end{array}$ & 0 & 50 & 16.4 & No change & $\begin{array}{c}\text { mostly } 3 \& 7 \text {, very few } \\
\text { immediate }\end{array}$ \\
\hline 04 & $\begin{array}{l}\text { Dairy produce; eggs; } \\
\text { natural honey }\end{array}$ & 8 & 176 & 58 & $\begin{array}{l}\text { same, very few } \\
5 \& 10 \mathrm{yrs}\end{array}$ & $\begin{array}{c}\text { mostly } 10 \text { yrs, very few } \\
\text { immediate }\end{array}$ \\
\hline 05 & $\begin{array}{l}\text { Products of animal } \\
\text { origins }\end{array}$ & 0 & 27 & 9 & $\begin{array}{l}\text { mostly immediate } \\
\& 5 \text { yrs, very few } \\
\text { same }\end{array}$ & mostly immediate \\
\hline 07 & Edible vegetables & 0 & 887.4 & 114.7 & No change & $\begin{array}{c}\text { mostly immediate \& } \\
10 \mathrm{yrs}\end{array}$ \\
\hline 08 & Edible fruit and nuts & 8 & 611.5 & 65 & $\begin{array}{c}\text { Mostly no change, } \\
\text { very few } 5 \text { and } \\
10 \mathrm{yrs}\end{array}$ & $\begin{array}{c}\text { mostly immediate \& } \\
10 \mathrm{yrs}\end{array}$ \\
\hline 14 & $\begin{array}{l}\text { Vegetable plaiting } \\
\text { materials }\end{array}$ & 3 & 8 & 5 & $\begin{array}{c}\text { mostly } 10 \text { yrs, very } \\
\text { few } 5 \& 7 \text { years }\end{array}$ & $\begin{array}{c}\text { mostly immediate \& } 5 \\
\text { yrs, very few } 10 \text { yrs }\end{array}$ \\
\hline 16 & $\begin{array}{l}\text { Preparations of meat, of } \\
\text { fish or of crustaceans }\end{array}$ & 18 & 72 & 23.6 & mostly 10 yrs & mostly $3 \& 5$ yrs \\
\hline 17 & $\begin{array}{l}\text { Sugars and sugar } \\
\text { confectionery }\end{array}$ & 3 & 243 & 18.8 & $\begin{array}{c}\text { mostly same \& } \\
10 \mathrm{yrs}\end{array}$ & $\begin{array}{c}\text { mostly } 0 \& 5 \text { yrs, very } \\
\text { few } 10 \text { yrs }\end{array}$ \\
\hline
\end{tabular}




\begin{tabular}{|c|c|c|c|c|c|c|}
\hline 18 & $\begin{array}{l}\text { Cocoa and cocoa } \\
\text { preparations }\end{array}$ & 2 & 40 & 11 & mostly $5 \& 10$ yrs & mostly 0 , a few 12 yrs \\
\hline 20 & $\begin{array}{l}\text { Preparations of } \\
\text { vegetables, fruit, nuts or } \\
\text { other parts of plants }\end{array}$ & 5 & 63.9 & 34 & $\begin{array}{c}\text { mostly same, very } \\
\text { few } 5 \& 7 \mathrm{yrs}\end{array}$ & $\begin{array}{c}\text { mostly } 5 \text { yrs, very few } \\
10 \text { yrs }\end{array}$ \\
\hline 21 & $\begin{array}{l}\text { Miscellaneous edible } \\
\text { preparations }\end{array}$ & 8 & 754.3 & 35 & $\begin{array}{c}\text { mostly } 10 \text { yrs, very } \\
\text { few immediate }\end{array}$ & $\begin{array}{l}\text { mostly immediate \& } 5 \\
\text { yrs, very few } 7 \& 10 \mathrm{yrs}\end{array}$ \\
\hline 22 & $\begin{array}{l}\text { Beverages, spirits and } \\
\text { vinegar }\end{array}$ & 8 & 270 & 21 & $\begin{array}{c}\text { mostly } 10 \text { yrs, very } \\
\text { few immediate and } \\
\text { same }\end{array}$ & mostly $0 \& 5$ yrs \\
\hline 25 & $\begin{array}{l}\text { Salt; sulphur; earths } \\
\text { and stone; plastering } \\
\text { materials, lime and } \\
\text { cement }\end{array}$ & 0 & 8 & 3.3 & $\begin{array}{c}\text { mostly immediate, } \\
\text { very few } 5 \& 7 \\
\text { yrs }\end{array}$ & mostly 0 , very few 3 yrs \\
\hline 26 & Ores, slag and ash & 0 & 2 & 0.6 & immediate & immediate \\
\hline 34 & $\begin{array}{l}\text { Soap, organic surface- } \\
\text { active agents, washing } \\
\text { preparations }\end{array}$ & 2 & 8 & 6.5 & immediate & mostly 0 , very few 7 yrs \\
\hline 43 & $\begin{array}{l}\text { Furskins and artificial } \\
\text { fur }\end{array}$ & 3 & 16 & 9.1 & $\begin{array}{c}\text { mostly } 0, \text { very few } \\
5 \mathrm{yrs}\end{array}$ & immediate \\
\hline 57 & $\begin{array}{l}\text { Carpets and other } \\
\text { textile floor coverings }\end{array}$ & 10 & 10 & 10 & immediate & immediate \\
\hline 61 & $\begin{array}{l}\text { Articles of apparel and } \\
\text { clothing accessories, } \\
\text { knitted }\end{array}$ & 8 & 13 & 12.8 & immediate & immediate \\
\hline 62 & $\begin{array}{l}\text { Articles of apparel and } \\
\text { clothing accessories, } \\
\text { not knitted }\end{array}$ & 8 & 13 & 12.6 & immediate & immediate \\
\hline 68 & $\begin{array}{l}\text { Articles of stone, } \\
\text { plaster, cement, } \\
\text { asbestos, mica }\end{array}$ & 8 & 8 & 8 & $\begin{array}{c}\text { mostly immediate, } \\
\text { very few } 5 \text { yrs }\end{array}$ & $\begin{array}{l}\text { mostly immediate, very } \\
\text { few } 3 \& 5 \text { yrs }\end{array}$ \\
\hline 70 & Glass and glassware & 0 & 8 & 7.4 & immediate & $\begin{array}{c}\text { mostly immediate, very } \\
\text { few } 3 \& 5 \text { yrs }\end{array}$ \\
\hline
\end{tabular}

Source: Author's calculation from Korea Customs Service FTA Portal

Table 2 reveals interesting results; tariff reductions in product groups where there is a potential market in Korea for Turkish exporters is either very limited or the time required for tariff-free trade is very long. Tariff removal schemes in the Korea-EU FTA for most of the products examined above show that Korea does not follow an effective policy to protect those markets for foreign competition. For the products having very high average pre-FTA tariff levels like meat $(23 \%)$, dairy products $(58 \%)$ vegetables (114.7\%) and fruits (65\%) Korea agreed on an immediate tariff removal of a gradual reduction scheme between 3 to 10 years. On the other hand, the tariff rates are mostly kept the same for the same product groups with Korea's FTA with Turkey. 
To repeat the characteristic of the product groups in the Table; these are the products that Korea gives a trade deficit and produces in little amounts and Turkey gives a trade surplus. It can be easily assumed that for the above mentioned products, Korean goods pose little threat for Turkish producers.

This situation reveals the typical FTA strategy of Turkey: "Agriculture is sensitive"; however this strategy fails to produce meaningful consequences in certain situations. To mention two specific cases; Korea is not a significant producer of dairy products and wine; Korea's geographical situation and agricultural background are limiting factors for Korea to become competitive for these products. As for wine, the duties in the Korean markets were removed at the first day of the implementation of the FTA with the agreement with Chile in 2004 and with the EU in 2011. Before the FTA, tariff rates for wine were $8 \%$ for Chile and $15 \%$ for the EU. Chilean wines, which were very low in import volume before the early 2000s, have become very popular in Korea after 2004, the year Korea and Chile signed an FTA. Only 2.4\% of imported wines in Korea were originated from Chile in 2000 with a trade value less than $\$ 500,000$. However following a sharp rise after 2004, Chilean wine exports reached $\$ 38$ million in 2014 with a share of $20.5 \%$ in Korean exported wine market ${ }^{11}$.

In the Turkey-Korea FTA, the agreement set a tariff removal for both parties after 10 years as Turkey wanted to "protect" its wine market against the competition of almost non-existent imports from Korea. The situation is very similar in the case of dairy products; Korea agreed to remove its tariffs on cheese immediately in its FTA with the EU (where the customs-free entrance is subject to a gradually increasing quota), but the high tariff rate of $36 \%$ is kept the same in the agreement with Turkey, again because Turkey is "protecting" its markets against Korean cheese. As a result, despite the fact that Turkish exports of dairy products and wine have increased in the recent years (especially the exports of dairy products have increased by almost fivefold in the last five years) Turkey have not seen a significant change in its exports of wine and dairy products to Korea after the FTA. As for total trade, Turkish exports to Korea increased by only $2 \%$ after the FTA, while Turkey's exports to the world have seen a $4 \%$ increase $^{12}$.

\section{Conclusion}

As the EU continues signing FTAs, Turkey is expected to lose its share in EU markets as other partners of the EU secure improved access by means of FTAs. EU's partners (like Mexico and South Africa) refrain from concluding FTAs with Turkey as the "Turkey Clause" is non-binding and even if the partners decide to sign an agreement (as in the case of Korea), Turkey faces a "latecomer" effect. It is also the fact that Turkey cannot choose its trade partners independently.

According to Akman ${ }^{13}$, if Turkey needs more market access (or to preserve its

11 Trade values from UN COMTRADE database (2015)

12 Ibid.

13 Akman,S., “The European Union's Trade Strategy and Its Reflections on Turkey: An Eva- 
current market share), it has to become more competitive for export purposes because "the Customs Union is not a unilateral life-long guarantee to keep its preferential status in European markets". However, even simple cases shown above indicate that Turkey is far from sufficiently taking advantage from the FTAs signed after the EU, where in many cases Turkey could have easily taken the third country's FTA with EU as a baseline and proceed the negotiations accordingly, but the protectionist instincts in certain sectors may result as lost opportunities.

It is obvious that the EU will continue its efforts to liberalize its trade with large markets, like Canada and USA. Despite requests and efforts from Turkey to have an active part in the EU's FTA negotiations ${ }^{14}$, it is also obvious that the EU will neither invite Turkey to the negotiation table in its future FTAs nor include a binding "Turkey clause" to those agreements as the EU has no obligation to do such a move in a process that is already complicated and hard to proceed. In this respect, Customs Union, or more generally the economic integration between Turkey and the EU is at a crossroads. The options that the policy makers discuss range from quitting the Customs Union and turning the agreement into an FTA to simply doing nothing and waiting for the day of the full membership. As the ultimate target of the European integration is membership to the EU, a major step backwards as quitting the Customs Union does not seem reasonable. On the other hand, every FTA of the EU means major losses in trade and customs revenues for Turkey. The only positive aspect of this puzzle could be that, this may be an incentive for Turkey to accelerate its efforts on its harmonization with the EU acquis and an eventual EU membership.

luation From the Perspective of Free Trade Agreements", Dokuz Eylül Üniversitesi Sosyal Bilimler Enstitüsü Dergisi. 12 (2):17-45

14 See TUSIAD (2008) and Gürlesel and Alkin (2010) 


\section{References}

ADAM, A. and Moutos, T., "The Trade Effects of the EU Turkey Customs Union". World Economy. 31 (5), 2008, pp. 685-700

AKMAN, S., "The European Union's Trade Strategy and Its Reflections on Turkey: An Evaluation from the Perspective of Free Trade Agreements", Dokuz Eylül Üniversitesi Sosyal Bilimler Enstitüsü Dergisi. 12 (2), 2010, pp. 17-45

European Commission, Global Europe: Competing in the World, Commission Staff Working Document, DG External Trade, Brussels, 2006

FRANCOIS, J. F., McQueen, M. and Wignaraja G. "European Union-developing country FTAs: overview and analysis", World Development 33(10), 2005, pp: 1545-1565.

GÜRLESEL, C. F. and Alkin, K., Avrupa Birligi'nin Serbest Ticaret Anlasmalarina Türkiye'nin de Dahil Edilmesi, ITO yayinlari, -18, 2010

KAMINSKI, B. and Ng, F., Turkey's Evolving Trade Integration Into Pan-European Markets. Journal of International Trade and Diplomacy. 1 (2), 2007, pp: 35-103

KANTER, J. and Ewing, J., A Running Start for a U.S.-Europe Trade Pact, The New York Times, 13.02.2013: http://www.nytimes.com/ 2013/02/14/business/global/obama-pledges-trade-pact-talks-with-eu.html

Korea Customs Service FTA Portal http://www.customs.go.kr/kcshome/ main/content/ContentView.do?contentId=CONTENT_ID_000002349\&layoutMenuNo=23266, 2015

KRUEGER, A. O., Problems with Overlapping Free Trade Areas, in Regionalism versus Multilateral Trade Arrangements Ito, T and Krueger, A. O. (eds.), University of Chicago Press, 1997

LAMY, P., "Stepping Stones or Stumbling Blocks? The EU's Approach Towards the Problem of Multilateralism vs Regionalism in Trade Policy", World Economy. 25, 2002, pp: 1399-1413

Republic of Turkey Ministry of Economy FTA portal http://www.ekonomi.gov.tr/sta/, 2015

Secretariat General for EU Affairs, Turkey-EC Customs Union Agreement:http:// www.abgs.gov.tr/files/_files/Gumruk_Isbirligi/okk1.pdf

TUSIAD, Gümrük Birliği Çerçevesinde AB'nin Üçüncü Ülkelerle Yaptığı Serbest Ticaret Anlaşmalarının Avrupa ve Türk İş Dünyasına Etkileri, TÜSİAD-T/2008-06-467., 2008

United Nations COMTRADE Statistics Database, http://comtrade.un.org/db /, 2015 